\title{
PREDISPOSING FACTORS RESPONSIBLE FOR THE OCCURRENCE OF BACTERIAL PURULENT MENINGOENCEPHALITIS
}

\author{
Brankica Dupanović ${ }^{1}$, Olgica Gajović ${ }^{2}$, Dragica Terzić ${ }^{1}$, Bogdanka Andrić1, \\ Zoran Todorović ${ }^{2}$, Branko Jakovljević ${ }^{3}$ and Danko Zivković ${ }^{1}$
}

${ }^{1}$ Clinical Center of Montenegro, Podgorica, Montenegro; ${ }^{2}$ Kragujevac Clinical Center, Kragujevac; ${ }^{3}$ Institute for Hygiene and Medical Ecology, School of Medicine, University of Belgrade, Belgrade, Serbia

\begin{abstract}
SUMMARY - Bacterial purulent meningoencephalitis (BPME) is a life-threatening infectious disease caused by various pyogenic bacteria. The disease is defined as the inflammatory process of leptomeninges (visceral layer, pia mater and arachnoid membrane) and brain parenchyma with exudates in the subarachnoid space and surrounding brain structures. The aim of the study was to define the predisposing factors responsible for the occurrence of BPME, as well as the possible correlation between the presence of predisposing factors and patient demographic characteristics, etiology and outcome of the disease. This retrospective-prospective study included 90 patients with BPME confirmed by clinical, neuroradiological and laboratory findings. Multivariate logistic regression models were fitted to analyze the impact of the predisposing factors on the disease outcomes. Predisposing factors that were related to BPME were found in $61 \%$ of patients. Cranial trauma as the leading factor was recorded in $23.3 \%$ of patients, followed by previous neurological disease in $14.4 \%$ of patients, while 13 patients were exposed to previous chemotherapy or long-term corticosteroid therapy. Cardiovascular diseases were reported in $12.2 \%$ and diabetes in $7.8 \%$ of patients. The existence of cardiovascular diseases significantly influenced unfavorable outcome of the disease, i.e. "deceased" in comparison to "cured" (OR=8.418; 95\% CI=1.007-76.270), independently of age and gender. None of the examined predisposing factors was significantly related to the "recovered with sequels" outcome as compared with "cured" outcome. Older age and presence of cardiovascular disease as a predisposing factor significantly increased the odds of the BPME unfavorable outcome "deceased" as compared to "cured" outcome.
\end{abstract}

Key words: Meningitis, bacterial; Meningoencephalitis; Treatment outcome; Causality

\section{Introduction}

The problem of bacterial purulent meningoencephalitis (BPME) is real today, both in the world and in our country. Most frequently, the disease occurs as a result of a particular predisposition, i.e. conditions that provoke the occurrence of the disease, as well as direct risk factors. It appears more often in persons with previously acquired brain or 'general' diseases. The ana-

Correspondence to: Prof. Danko Živkovic, $M D, P h D$, S. Kovačevića 65, 81400 Nikšić, Montenegro

E-mail: dankoz@t-com.me

Received June 30, 2015, accepted December 6, 2016 tomic integrity of bone structures in the endocranium, as well as a healthy immune system protecting against the infection of endocranium is important ${ }^{1}$. Neurological and mental disorders acquired before the onset of BPME greatly increase the risk of the disease, as well as sequel delay, although the specific structures of the blood-cerebrospinal fluid and blood-brain barriers bear the risk of intracranial infection (low values of immunoglobulin and complement, etc. $)^{2,3}$. The predisposition points to general weakness of the immune system in responding to the infection. Among the predisposing factors, the states of immunosuppression (AIDS, immunosuppressive and cytostatic therapy for 
malignancy, systemic diseases of the connective tissue, splenectomy, neutropenia, and defects of neutrophils) have been recorded in particular. Other predisposing factors responsible for the onset of the disease are alcoholism, diabetes, diseases of the cardiovascular system, kidney diseases, repeated infectious diseases, and heart defect with right-to-left shunt ${ }^{4,5}$.

Considering risk factors, most authors in the world and in our region ${ }^{4,5}$ primarily report on suppurative otitis media, mastoiditis, chronic and acute sinusitis (frontal, ethmoid and sphenoid), cranial trauma with fracture and residual bone fragments ${ }^{6}$, penetrating injuries of the head ${ }^{7,8}$ with rhinorrhea, etc. Approximately one of four people with rhinorrhea experience BPME, with frequent relapses 9 . It is unknown how predisposing factors affect disease outcome in patients with BPME. According to literature data, the risk factors and their impact on the course and outcome of the disease vary considerably ${ }^{10-13}$. Therefore, it is necessary to define the predisposing factors that are of paramount importance in each individual region.

The aims of this study were to identify the predisposing factors important for the development of BPME and the possible link between the presence of predisposing factors and demographic and etiologic characteristics with the disease outcome.

\section{Patients and Methods}

\section{Patients}

The Clinical Department for Infectious Diseases, Clinical Center of Montenegro (CDICCM) provides medical treatments in the area of infectious diseases for children older than 3 years and adults, with a catchment population of 600,000 . Included were medical records of patients with BPME in which the etiologic cause of the disease was isolated from their cerebrospinal fluid (CSF) samples, and who were treated at our Department and at the Institute for Infectious and Tropical Diseases in Belgrade, in the period from January 1,1995 until December 31, 2000.

\section{Data collection and definition of cases}

The study was based on the analyses of medical records of patients treated during the 1995-1998 period and the prospective study conducted in the 1998-2000 period. The following data were collected: biographic data, history of diseases, auto- and hetero-history data, especially those referring to the possible predisposing factors; objective neurological and somatic findings; cytologic, biochemical and bacterial CSF findings; laboratory findings, i.e. indicators of tissue inflammation in serum; data and direct insight into therapy, course, outcome and sequels. The diagnosis was established by clinical features, objective findings, and positive CSF finding. According to the disease outcome, all patients were stratified into three groups: cured, recovered and those that died. Patients were also stratified by the presence of specific risk factors and microbiological isolates.

\section{Data processing and analysis}

Considering the methods of descriptive statistics, we used measures of central tendency (arithmetic mean), variability measures (standard deviation, standard error, range, minimum, maximum and variant), as well as the tests to evaluate distribution. On analytical statistics, we employed $\chi^{2}$-test, $T$ test for paired samples, $\mathrm{T}$ test for unpaired (independent) samples, and ANOVA.

\section{Results}

During the six-year period, the study included 90 patients affected by BPME; the outcome of the disease was reported for 85 patients. The mean age was $49.7 \pm 20.6$ years. Thirty-eight $(44.7 \%)$ patients were cured, $18(21.2 \%)$ patients were recovered with sequels, and $29(34.1 \%)$ patients died. General characteristics of patients according to the three outcomes observed (cured, recovered with sequels and deceased) are shown in Table 1 . The patients that died were significantly older than those that were cured or recovered with sequels. The majority of patients with all outcomes were male, but differences among the three outcome groups were not statistically significant. In addition, the three outcome groups were similar by the number of predisposing factors or risk factors (Table 1).

Etiologic and bacteriological CSF examinations were carried out in all patients. The most frequent cause of BPME was Streptococcus pneumoniae, which was isolated in 47 (55.0\%) patients, followed by Staphylococcus aureus in nine (10.5\%) and Neisseria meningitides in six (7.0\%) patients. The majority of patients 
Table 1. General characteristics of study population according to bacterial purulent meningoencephalitis outcome

\begin{tabular}{|c|c|c|c|c|c|c|c|}
\hline \multicolumn{2}{|l|}{ Characteristic } & Cured & $\begin{array}{l}\text { Recovered } \\
\text { with sequels }\end{array}$ & Deceased & Total & Test value & $\mathrm{p}$ value \\
\hline \multicolumn{2}{|l|}{ Age (years) } & $43.2 \pm 21.6$ & $44.1 \pm 17.6$ & $61.7 \pm 15.8$ & $49.7 \pm 20.6$ & $8.876^{*}$ & 0.000 \\
\hline \multirow{2}{*}{ Gender, n (\%) } & Male & $22(57.9 \%)$ & $12(66.7 \%)$ & $15(51.7 \%)$ & $49(57.6 \%)$ & \multirow{2}{*}{$1.017^{\#}$} & \multirow{2}{*}{0.601} \\
\hline & Female & $16(42.1 \%)$ & $6(33.3 \%)$ & $14(48.3 \%)$ & $36(42.4 \%)$ & & \\
\hline \multirow{3}{*}{$\begin{array}{l}\text { Number of } \\
\text { predisposing } \\
\text { factors (\%) }\end{array}$} & None & $17(44.7 \%)$ & $7(38.9 \%)$ & $9(31.0 \%)$ & $33(38.8 \%)$ & \multirow{3}{*}{$1.503^{\#}$} & \multirow{3}{*}{0.826} \\
\hline & 1 & $16(42.1 \%)$ & $8(44.4 \%)$ & $14(48.3 \%)$ & $38(44.7 \%)$ & & \\
\hline & $\geq 2$ & $5(13.2 \%)$ & $3(16.7 \%)$ & $6(20.7 \%)$ & $14(16.5 \%)$ & & \\
\hline \multirow{3}{*}{$\begin{array}{l}\text { Number of risk } \\
\text { factors }(\%)\end{array}$} & None & $11(28.9 \%)$ & $6(33.3 \%)$ & $13(44.8 \%)$ & $30(35.3 \%)$ & \multirow{3}{*}{$2.006^{\#}$} & \multirow{3}{*}{0.735} \\
\hline & 1 & $21(55.3 \%)$ & $9(50.0 \%)$ & $13(44.8 \%)$ & $43(50.6 \%)$ & & \\
\hline & $\geq 2$ & $6(15.8 \%)$ & $3(16.7 \%)$ & $3(10.4 \%)$ & $12(14.1 \%)$ & & \\
\hline
\end{tabular}

"ANOVA; ${ }^{*} \chi^{2}$-test

(42\%) were cured, $32 \%$ died and 20\% recovered with sequels (data not shown).

The predisposing factor responsible for the onset of bacterial purulent meningitis was analyzed in all patients. Predisposing factors were found in 52 (61.2\%) patients. One predisposing factor was present in $44.7 \%$ of patients, while two or more concurrent factors were found in $16.5 \%$ of patients (Table 1). Because of the large number of various predisposing factors, particular predisposing factors were grouped as shown in $\mathrm{Ta}-$ ble 2 . The most frequent previous disease was cranial trauma (old head injury and neurosurgical intervention), which was recorded in 21 (23.3\%) patients. Neurological disease and chemotherapy or long-term treatment with corticosteroids were recorded in 13 (14.4\%) patients each. Chronic heart or cardiovascular disease was found in 11 (12.2\%), diabetes mellitus in seven (7.8\%), alcoholism in six (6.7\%) patients, while splenectomy had been performed in two (2.2\%) patients (Table 2).

Analysis of the relations between the etiologic cause and presence of predisposing factors did not yield any significant difference, although Staphylococcus, Pneumococcus and gram-negative bacteria were more often the cause of BPME in patients with predisposing factors (Fig. 1).

Distribution of the selected predisposing factors according to outcome of the disease is shown in Table 3. The three predisposing factors of cranial trauma, immunosuppression and neurological diseases were found to be equally distributed among the three outcome groups. Nevertheless, cardiovascular diseases
Table 2. Prevalence of particular predisposing factors

\begin{tabular}{|l|l|l|}
\hline Predisposing factor & $\mathrm{n}$ & $\%$ \\
\hline $\begin{array}{l}\text { Cranial trauma (old head injury } \\
\text { and neurosurgical intervention) }\end{array}$ & 21 & 23.3 \\
\hline $\begin{array}{l}\text { Neurological diseases } \\
\text { (cerebrovascular insult, epilepsy, } \\
\text { subarachnoid hemorrhage, aneurysm) }\end{array}$ & 13 & 14.4 \\
\hline $\begin{array}{l}\text { Immunosuppression (lymphoma } \\
\text { and leukosis, tumors, systemic diseases } \\
\text { of the connective tissue) }\end{array}$ & 13 & 14.4 \\
\hline Diabetes mellitus & 7 & 7.8 \\
\hline Alcoholism & 6 & 6.7 \\
\hline Cardiovascular diseases & 11 & 12.2 \\
\hline Condition after splenectomy & 2 & 2.2 \\
\hline
\end{tabular}

were the only predisposing factor that was significantly more frequently observed among persons that died as compared with the other two outcomes (Table 3).

Logistic regression was performed to assess the influence of the above-mentioned predisposing factors on the disease outcome (Table 4). Two statistical models were fitted: in Model 1, the unfavorable outcome 'death' was compared to the favorable outcome 'cured'; and in Model 2, the unfavorable outcome 'recovered with sequels' was compared to the favorable outcome 'cured'. All included variables were identical in both models. Older age and the presence of cardiovascular diseases as predisposing factors increased significantly the odds of the unfavorable outcome 'deceased' as compared with 'cured' in Model 1. None of the investigated predisposing factors (cranial trauma, neuro- 


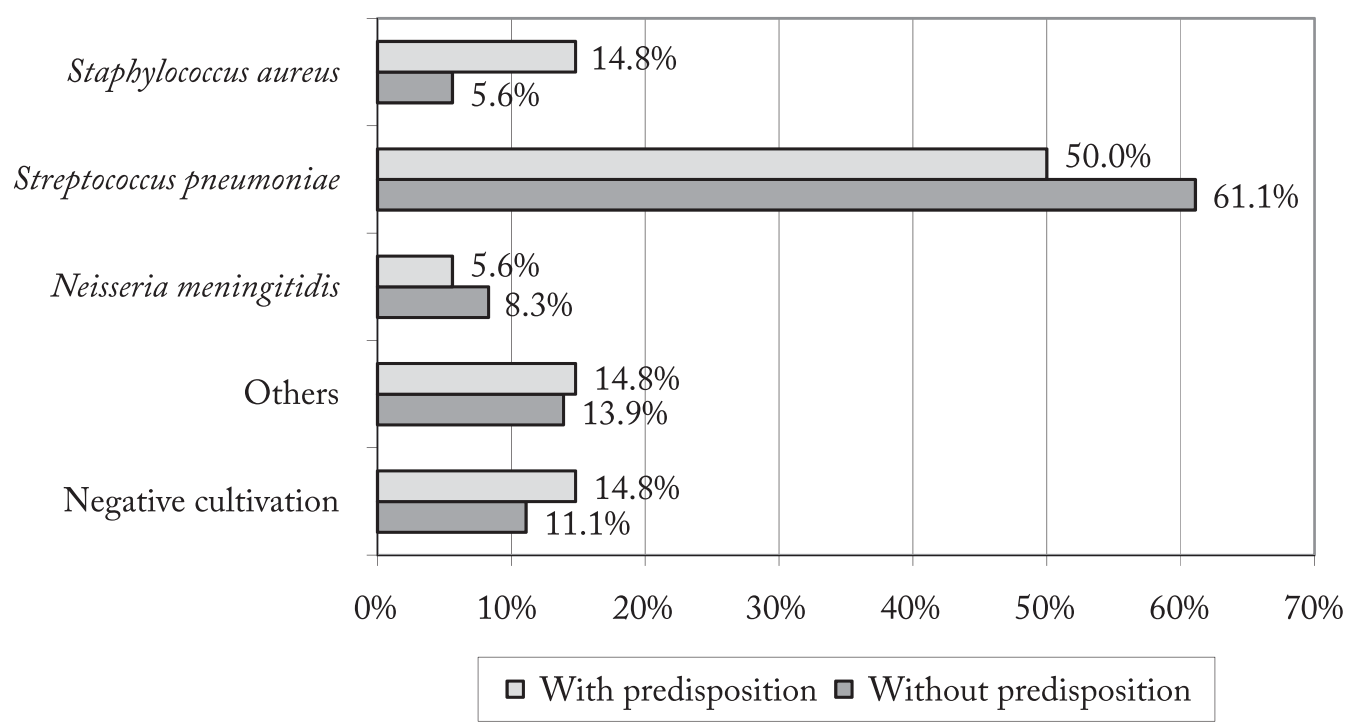

$\chi^{2}$-test $=2.642 ; \mathrm{p}=0.619$

Fig. 1. Relation between predisposition and etiologic cause of the disease.

Table 3. Distribution of predisposing factors according to outcome of the disease

\begin{tabular}{|l|l|l|l|l|l|}
\hline \multirow{2}{*}{ Predisposing factor } & \multicolumn{4}{|c|}{ Outcome of the disease } & \multirow{2}{*}{ p value } \\
\cline { 2 - 6 } & Cured & $\begin{array}{l}\text { Recovered } \\
\text { with sequels }\end{array}$ & Deceased & Total & \\
\hline Cranial trauma & 11 & 6 & 3 & 20 & $0.535^{*}$ \\
\hline Immunosuppression & 4 & 2 & 7 & 13 & $0.231^{*}$ \\
\hline Neurological diseases & 4 & 3 & 5 & 12 & $0.531^{*}$ \\
\hline Cardiovascular diseases & 1 & 2 & 8 & 11 & $\mathbf{0 . 0 1 8}^{*}$ \\
\hline
\end{tabular}

${ }^{*} \chi^{2}$-test

Table 4. Odds ratios (95\% confidence intervals) for unfavorable outcomes 'deceased' or 'recovered with sequels' vs. 'cured' in the study population with bacterial purulent meningoencephalitis

\begin{tabular}{|l|l|l|l|l|}
\hline \multirow{2}{*}{ Variable } & \multicolumn{2}{|l|}{ Model 1 - 'deceased' vs. 'cured' } & \multicolumn{2}{l|}{$\begin{array}{l}\text { Model 2 - 'recovered } \\
\text { with sequels' vs. 'cured' }\end{array}$} \\
\cline { 2 - 5 } & Odds ratio & $95 \%$ CI & Odds ratio & $95 \%$ CI \\
\hline Gender: male & 0.815 & $0.275-2.414$ & 0.499 & $0.135-1.849$ \\
\hline Age (years) & 1.047 & $1.013-1.082$ & 1.002 & $0.961-1.044$ \\
\hline Cardiovascular diseases & 8.418 & $1.007-76.270 *$ & 6.073 & $0.428-86.138$ \\
\hline Cranial trauma & 0.680 & $0.105-4.397$ & 1.145 & $0.291-4.511$ \\
\hline Neurological diseases & 2.353 & $0.308-17.993$ & 1.463 & $0.211-10.144$ \\
\hline Immunosuppression & 3.073 & $0.595-15.865$ & 0.790 & $0.112-5.569$ \\
\hline
\end{tabular}

"statistically significant, $\mathrm{p}<0.05$ 
logical diseases, immunosuppression, and cardiovascular diseases) was related to the unfavorable outcome 'recovered with sequels' as compared with 'cured' in Model 2.

\section{Discussion}

Bacterial purulent meningoencephalitis poses a serious medical problem even today. The death rate from the disease, despite the improved diagnostics, use of powerful antibiotics and other therapeutic methods, is relatively high, i.e. up to $30 \%{ }^{3,10-13}$. The majority of patients are over 40 years old, which makes $63 \%$ or $70 \%$ of treated persons. The occurrence of BPME in adults is more often associated with the presence of a predisposing factor and direct risk such as immunosuppression, head trauma and chronic infections ${ }^{4,14-16}$. In our patients, the proportion of elderly persons was high, implying greater likelihood of poor outcome. Other authors report similar data ${ }^{11}$.

The presence of a predisposing factor responsible for the onset of BPME was found in $61 \%$ of our patients. Study results showed prior cranial trauma (23.3\% of cases), old neurosurgical intervention (detected in 12 or $13.3 \%$ of patients) and head trauma (present in 14 or $15.6 \%$ of patients) to be most frequently present. At the same time, the presence of head trauma or old neurosurgical intervention was detected in six $(6.8 \%)$ patients ${ }^{4,17}$.

Neurological disease is a significant predisposing factor for the occurrence of BPME. In our patients, their medical history revealed epilepsy in 11 (12.2\%), cerebrovascular insult in three (3.3\%), brain tumor in two $(2.2 \%)$ cases, and subarachnoid hemorrhage in one patient. Stanek and Mufson report that neurological and neurosurgical diseases as predisposing factors were present in 15 (29\%) patients ${ }^{18}$.

Diabetes as a predisposing factor was present in $7.9 \%$ of our patients. Durand et al. point to diabetes and alcoholism as predisposing factors responsible for the onset of the disease ${ }^{19}$. In diabetes patients, the risk of infection is increased due to reduced protein synthesis and hyperglycemia that inhibits the process of phagocytosis, as well as by energy deficit that influences macrophage activity ${ }^{20,21}$. Alcoholism as a predisposing factor was present in $6.7 \%$ of our patients. In their study, Van de Beek et al. report that $6 \%$ of patients with pneumococcal meningitis had this predis- posing factor ${ }^{22}$. Persons who consume alcohol suffer from immunosuppression, malnutrition, brain atrophy, alcoholic epilepsy and encephalopathy of alcoholic genesis, which all together represent the predisposing factors responsible for the occurrence of BPME. Other authors report similar results ${ }^{23,24}$. In chronic ethylism cases, aside from metabolic disorders and immunodeficiency, cranial traumas were more frequently observed, which contribute to the incidence of bacterial infections ${ }^{25,26}$.

Hematologic malignancies (lymphoma, leukosis, etc.) were found in six patients. Pruitt underlines malignancy as a risk factor responsible for the appearance of bacterial infections of the nervous system ${ }^{27}$.

Systemic diseases of the connective tissue were also found in patients affected by BPME. Corticoid therapy causes lymphopenia, monocytopenia and eosinopenia ${ }^{28}$. Patients with cellular immunity disorder were receiving daily corticosteroid therapy. Corticosteroids inhibit the synthesis of prostaglandins and leukotrienes, and reduce blood vessel permeability and histamine release from basophilic leukocytosis generating disorder of cellular immunity. Therefore, these patients are more prone to infections of the nervous system caused by intracellular microorganisms, the elimination of which requires intact T-lymphocyte-macrophage system ${ }^{29}$. Systemic lupus erythematosus was detected as the predisposing factor in two $(2.2 \%) \mathrm{pa}^{-}$ tients, while vasculitis and Sjögren's syndrome were found in one patient each. All these patients underwent long-term corticosteroid therapy. Bahal and $\mathrm{Na}-$ hata emphasize the importance of the long-term usage of corticosteroids as a predisposing factor for the occurrence of $\mathrm{BPME}^{28}$. The presence of staphylococcus as a cause of BPME was more often recorded in patients with some of the predisposing factors. There was no significant difference among particular predisposing factors and causes of the disease, although staphylococcus induced the appearance of BPME more often when there was immunosuppression as a predisposing factor.

The presence of predisposing factors did not significantly influence the type of etiologic cause of BPME. Nevertheless, the presence of cardiovascular diseases was significantly related to the type of outcome. Patients with cardiovascular diseases had higher odds of the unfavorable outcome 'death' in comparison to the favorable outcome 'cured'. McMillan et al. un- 
derline the importance of comorbidity for the outcome of the disease, emphasizing that cardiovascular disease is a poor prognostic factor. In our study, patients with the predisposing cardiovascular disease were older at the same time, which may greatly influence lethal outcome ${ }^{30}$.

\section{Conclusion}

The predisposing factors responsible for the occurrence of BPME, found in $61 \%$ of our patients, were cranial trauma, neurological disease (epilepsy, subarachnoid hemorrhage, cerebrovascular insult), diabetes, alcoholism, cardiovascular diseases, malignant hemopathies, systemic diseases of the connective tissue, and post-splenectomy states. Older age and the presence of cardiovascular diseases as a predisposing factor significantly increased the odds of the unfavorable outcome 'deceased' after BPME, when compared to the favorable outcome 'cured'. Cardiovascular diseases were not significantly related to the odds of another unfavorable outcome 'recovered with sequels' in comparison to the favorable outcome 'cured'.

\section{References}

1. Brouwer MC, Tunkel AR, van de Beek D. Epidemiology, diagnosis, and antimicrobial treatment of acute bacterial meningitis. Clin Microb Rev. 2010;23(3):467-92. doi: 10.1128/CMR. 00070-09.

2. Haines SJ, Goodman ML. Antibiotic prophylaxis in neurological surgery. Neurosurgery. 1980;6:355-61. PMID:6993984

3. Gray BM, Converse GM, Dillon HC. Epidemiologic studies of Streptococcus pneumoniae in infants: acquisition, carriage, and infection during first twenty four months of life. J Infect Dis. 1980;142:923-33.

4. Tunkel AR, Scheld WM. Pathogenesis and pathophysiology of bacterial infection of the central nervous system. In: Scheld WM, Whitley RL, Durack DT, editors. Raven Press, New York; 1991: p. 297-312.

5. Wispelwey B, Scheld WM. Brain abscess. In: Mandell GL, Douglas GE, Bennett JE, editors. Principles and Practices of Infectious Disease, $4^{\text {th }}$ edn. Churchill- Livingstone, New York; 1995: p. 887-900.

6. Tenney JH. Bacterial infection of the central nervous system in neurosurgery. Neurol Clin. 1986;4:91-114. PMID:3523205

7. Taha JM, Haddar FS, Brown JA. Intracranial infection after missile injuries to the brain: report of 30 cases from the Lebanese conflict. Neurosurgery. 1991;26 (6):864-8. PMID: PMID: 1758598
8. Besenski N, Jadro Santel D, Jelavic Koic F, et al. CT analysis of missile head injury. Neuroradiology. 1995;37(3):207-11.PMID 7603596

9. Dulović O. Nivoi leukotrijena u cerebrospinalnoj tečnosti u akutnim bakterijskim i virusnim infekcijama centralnog nervnog sistema. Doctoral dissertation. University of Belgrade, Belgrade; 1994. (in Serbian)

10. Šašić M. Cerebritis i moždani apsces. In: Šašić M, et al., editors. Infekcije nervnog sistema, $1^{\text {st }}$ edn. Belgrade; 2000: p. 400-14. (in Serbian)

11. Khwannimit B, Chayakul P, Geater A. Acute bacterial meningitis in adults: a 20 year review. Southeast Asian J Trop Med Public Health. 2004;35(4):886-92.

12. Boyles TH, Bamford C, Bateman K, et al. Guidelines for the management of acute meningitis in children and adults in South Africa. South Afr J Epidemiol Infect. 2013;28(1):5-15.

13. Ataee RA, Mehrabi-Tavana A, Izadi M, et al. Bacterial meningitis: a new risk factor. J Res Med Sci. 2011;16(2):207-10. PMID:22091233 PMCID:PMC3214305

14. Tracey KJ, Cerami A. Tumor necrosis factor in metabolism of disease: hormonal actions versus local tissue effect. Nouv Rev Fr Hematol. 1992;34(Suppl):53-42.

15. Grose GJ, Trupp LD, Nudleman KL, Wyle FA, Hawkins B, Cesario TC. Bacterial meningitis in the elderly. Arch Intern Med. 1984;144:1603-7. PMID:6466018

16. Behram RE, Meyers BR, Mendelson MH, Sacks HS, Hirshman SZ. Central nervous system infections in the elderly. Arch Intern Med. 1989;149:1596-9.

17. Lefrock JL, Smith BR. Gram-negative bacillary meningitis in adults. In: Vinken PJ, Bruyan GW, Klawans HL, Harris AA, editors. Handbook of Clinical Neurology. Elsevier, Amsterdam; 1988: p. 103-15.

18. Stanek JR, Mufson AM. A 20-year epidemiological study of pneumococcal meningitis. Clin Infect Dis. 1999;28:1265-72. PMID:10451164DOI:10.1086/514777

19. Durand ML, Calderwood SB, Weber DJ. Acute bacterial meningitis in adults: a review of 493 episodes. N Engl J Med. 1993;328:21-8. PMID:8416268DOI: 10.1056/NEJM199301 073280104

20. Krasinski K, Nelson JO, Batler S. Possible association of mycoplasma and viral respiratory infections with bacterial meningitis. Am J Epidemiol. 1987;125: 499-508.

21. Van de Beek D, de Gans J, Spaniaard L, et al. Clinical features and prognostic factors in adults with bacterial meningitis. $\mathrm{N}$ Engl J Med.2004;351:1849-59. DOI:10.1056/ NEJMoa040845

22. Van de Beek D, Weisfelet M, Hoogoman M, et al. Neuropsychological sequelae of bacterial meningitis: the influence of alcoholism and adjunctive dexamethasone therapy. Brain. 2006; 129(5):E46.

23. French SW. Acute and chronic toxicity of alcohol. In: Kissian B, Begleiter H, editors. The Biology of Alcoholism, Vol. 1. Plenum Press, New York; 1971:1-19. 
24. Calaspuro MP. Influence of ethanol on the metabolism of the protein deficient fatty liver. In: Martini GA, Bode Ch, editors. Metabolism Changes Induced by Alcohol. Springer Verlag, Berlin-New York; 1971:89-112.

25. Smith AL. Neurologic sequels of bacterial meningitis. N Engl J Med.1988;319:1012-3.DOI:10.1056/NEJM198810133191510

26. Stanbury JB, Wyngaarden JB, Fredrickson DS, et al. The Metabolic Basis of Inherited Diseases. McGraw-Hill, New York; 1983.

27. Pruitt AA. Central nervous system infections in cancer patients. Neurol Clin. 1991 Nov;9(4):867-88. PMID:1758429
28. Bahal N, Nahata MC. The role of corticosteroids in infants and children with bacterial meningitis. DICP 1991 May;25(5):5425. PMID:2068839

29. Rubin RH, Hooper DC. Central nervous system infections in the compromised host. Med Clin North Am. 1985;69:281-93. PMID:3990435

30. McMillan DA, Lin CY, Aronin SI, Quagliarello VJ. Community acquired bacterial meningitis in adults: categorization of cause and timing of death. Clin Infect Dis. 2001;33:969-75. DOI:10.1086/322612

Sažetak

\section{ČIMBENICI PREDISPOZICIJE ODGOVORNI ZA POJAVU BAKTERIJSKOG PURULENTNOG MENINGOENCEFALITISA}

\section{B. Dupanović, O. Gajović, D. Terzić, B. Andrić, Z. Todorović, B. Jakovljević i D. Živković}

Bakterijski gnojni (purulentni) meningoencefalitis (BPME) je za život opasna zarazna bolest uzrokovana različitim piogenim bakterijama. Bolest je definirana kao upalni proces leptomeninga (visceralni sloj, pia mater i arahnoidna membrana), parenhima mozga s eksudatom u subarahnoidnom prostoru i okolnim strukturama mozga. Cilj istraživanja bio je definirati predisponirajuće čimbenike koji su odgovorni za pojavu BPME, kao i moguću povezanost prisutnosti predispozicije i demografskih karakteristika bolesnika, etiologije i ishoda bolesti. Ovo retrospektivno-prospektivno istraživanje je obuhvatilo 90 bolesnika različite dobi s BPME kod kojih je bolest potvrđena na osnovi kliničkih, neuroradioloških i laboratorijskih nalaza. Utjecaj predisponirajućih čimbenika na ishod bolesti analiziran je logističkom regresijom. Čimbenici predispozicije vezani za pojavu BPME su pronađeni u 61\% bolesnika. Vodeći čimbenik je bila trauma lubanje zabilježena u 23,3\% bolesnika, zatim prethodna neurološka bolest u 14,4\% bolesnika, dok je 13 bolesnika bilo na kemoterapiji ili dugotrajnoj terapiji kortikosteroidima. Kardiovaskularne bolesti bile su prisutne u $12,2 \%$, a dijabetes u 7,8\% bolesnika. Postojanje kardiovaskularnih bolesti bilo je značajan predskazatelj smrtnosti kao nepovoljnog ishoda bolesti u usporedbi s ozdravljenjem (OR=8,418; 95\% $\mathrm{CI}=1,007-76,270)$, nezavisno od spola i dobi. Nijedan predisponirajući čimbenik nije bio statistički značajno povezan $s$ pojavom drugog nepovoljnog ishoda bolesti, "oporavka s posljedicama" u usporedbi s ozdravljenjem. U zaključku, bolesnici s BPME starije životne dobi i s postojećim kardiovaskularnim bolestima imali su značajno veću vjerojatnost nepovoljnog ishoda "smrti" u usporedbi s ozdravljenjem.

Ključne riječi: Meningitis, bakterijski; Meningoencefalitis; Ishod liječenja; Uzročnost 